\title{
Students' Perceptions about the Importance of Communication Skills: A Case Study of EFL Learners at Jazan University, Saudi Arabia
}

\author{
Muhammad Riaz Khan \\ Faculty, English Language Centre \\ Jazan University, P.O.Box 114, Jizan, Saudi Arabia \\ E-mail: riaz_khan655@yahoo.com \\ Shehla Riaz Khan \\ Faculty, English Language Centre \\ Jazan University, P.O.Box 114, Jizan, Saudi Arabia \\ E-mail: shehla1956@hotmail.com
}

Saeed Ahmad (Corresponding author)

Faculty, English Language Centre

Jazan University, P.O.Box 114, Jizan, Saudi Arabia

E-mail: saeed_edu@hotmail.com

Received: December 3, 2015 Accepted: December 22, 2015 Published: December 25, 2015

doi:10.5296/ijele.v4i1.8782 URL: http://dx.doi.org/10.5296/ijele.v4i1.8782

\begin{abstract}
The graduates of Jazan University (Saudi Arabia), like anywhere else in EFL or ESL settings, require effective oral communication skills in English language for a highly competitive and expanding market economy of the country, and the worldwide too. The study was taken to evaluate the students' perceptions about the need of speaking skills and the urgency to participate in language enhancement activities keeping in view the generally unsatisfactory position of the Saudi students in speaking English language. The sample population for this research was taken from three colleges, i.e. the first grade students from Engineering,
\end{abstract}


Business and Computer Science of this university. A survey method technique was adopted in which data was obtained using a structured questionnaire about students' responses on multiple items indicating their understanding of the importance of speaking skills, their existing level of oral communication and the need to participate in the extra coaching programs offered by the university. The quantitative data were analyzed by using SPSS 17. The data shows the participants' understanding of the importance of communication skills for social needs, personality development, attaining and survival in the job market, and their needs for attending extra language training sessions other than their normal routine courses.

Keywords: Communication Skills, English for Specific Purpose, Students' Perceptions, Extra Coaching

\section{Introduction}

English is the number one lingua franca in the world today, and a dominant language in the fields of commerce, education and tourism due to its apex position in the process of globalization, just as in the Middle Ages, for example, Latin served for a specific time the language for international communication. The countries in the Middle East are striving their best to equip their youth with English so as to make them able to compete with the rest of the world in grabbing jobs and scholarships at the international level. The importance of English for Saudi Arabia was first realized decades ago ( in 1920s) when it, for the first time in the history of Saudi Arabia, was included in the national curriculum to be taught as a foreign language (Ahmad \& Ahmad, 2015). The command on communication skills for social prestige and getting jobs in the multi-national companies in Saudi Arabia has recently been a topic of hot debate. A plethora of research is available on the need of improving communication skills for the English language learners, yet there is hardly found any study in the Saudi context to elaborate students' own perceptions on their existing communication skills and their needs to participate in the language training programs. With the involvement of modern technology in educational institutions, revolutionary changes in the new world of media, mass communication and internet, it has become inevitable for the students of professional courses to acquire command over English language (Harmer, 2012). Students in the fields of business, engineering and technology find it an essential part of their education to communicate verbally as well as in writing. By the end of the twentieth century, English was already on its way to become a genuine lingua franca that is a language used widely for communications between people who don't share the same first (or even second) language.

Due to the rapid progress of globalization, English has become one of the essential means of communication throughout the world. Of all the four skills (listening, speaking, reading and writing), speaking seems intuitively the most important: people who know a language are referred to as 'speakers ' of that language, as if speaking included all other kinds of knowing; and many, if not most, foreign language learners are primarily interested in learning to speak (Ur, 2008). Al -Ghunaimi (2003:2) states that:

Recently, it [English language] has been the language of "globalization". Therefore, 
English as a foreign language has been considered of importance in curriculum in most Arab countries to enable students to cope with modern life and develop their countries.

Oral communication is the greatest use of language and is the basis of communication; in fact, it is the basis of literacy. Likewise, Gillian $(2005,23)$ asserted that 'language plays a vital role in the personal and social development of students. It enables them to gain understanding of themselves and others, strengthens their social relationships'. Through oral communication, students learn about themselves, ideas, and feelings and become capable of responding to the communications of others, enabling students to participate in society successfully (Chanrung 2004).

\section{Background of the Study}

The poor speaking ability of students is a serious problem across the Kingdom of Saudi Arabia, and the students of Jazan university students are no exception. English language is an integral part of the syllabus in elementary and secondary schools; and also at the intermediate level in most of the universities at PYP (preparatory year program) all over the Kingdom. Although students learn English language for a long span of time (almost eight years) during their studies in the above mentioned educational institutions, but still most of them face difficulties when communicating in English in the classroom or in real life situations. There are many reasons for their poor speaking/oral skills. They only get a chance to practice language in the classroom, and unfavourable learning environment outside the classroom causes lack of motivation to them. Yasmin (2004:45) argues that the students' major difficulty arises from the fact they cannot use English correctly and appropriately either in the classroom or outside when they are required to do so. This means that the difficulty is related to the students' deficiencies in communicative competence and self-expression. Students find difficulties in using English for communication when they engage themselves in authentic communicative situations. They often lack in vocabulary or language items they need to get their meaning across (Rababah, 2003:45).

Furthermore, most of the students have the tendency to cram from books, even for learning technical skills (Ahmad \& Rao, 2012). They only study to pass the exams and the failure of testing system to include the required oral assessment/gradation in this connection aggravated the problem. Rababah (2003:89) argues that the continuing dissatisfaction with the performance of Arab students in English courses suggests a lack of fundamental standards in curriculum design, testing the oral communication skills and adopting appropriate teaching strategies at the university level. In the classroom, they have rarely been involved in communicative activities which is a great hindrance for learning the language for communication. Learning a foreign language is not an easy task. The problems could be related to different factors, the main two of them are: mother tongue interference and no real situation for applying what has been learned (EL- Majdalawi, 2005:45). Consequently, it leads to students' lack of exposure on how to learn English Language effectively, and it makes it even more challenging for the teachers to teach them English language in general and oral/speaking skills in particular. Saudi students have some opinion based on their prior knowledge but they cannot say exactly what they want. There are some motivational reasons 
but the main reason in this context is their lack of oral practice in the language. As Scrivener (2012), in EFL/ESL context in general and Saudi context in particular, elaborated this phenomenon in these words:

Very often when people study a language, they accumulate a lot of 'up-in-the-head' knowledge (i.e. they may know rule of grammar and list of vocabulary items), but then find that they cannot actually use this language to communicate when they want to. There seems to be some difficulty in moving language from 'up-there' knowledge to actively usable language. For many learners, their passive knowledge is much larger than their active language.

The Ministry of Education in the Kingdom is investing a large amount of money on recruiting highly qualified teachers from different parts of the world, on books and course materials, and offering scholarships for the Saudi students to study abroad, but majority of the students are still struggling in learning English language. There is an urgent need to adopt modern techniques, approaches and methodologies to bring improvement in the education system and to generate their interest particularly for learning English for communication at college/university level.

\subsection{Language Anxiety and Motivation for Communication}

The main objective of oral communication in the class is to get students use the target language to interact in realistic and meaningful ways. Ur (2008) claims that in order to get the pupils communicate with each other and express themselves freely in the target language, it is necessary to use interesting topics but more importantly the discourse must have a meaningful purpose. Brumfit (1998- as mentioned in Johnson \& Morrow 1986:48) claims that pupils in the foreign language classroom should frequently be exposed to the target language and they should be given opportunities to use the language. Contextualization of language, in this regard, has been shown to increase students' motivation (Cordova \& Lepper, 1996).

Motivating students to speak English who are reluctant/shy to speak in the class, providing them enough language support, feedback and encouragement are the main responsibilities of a language teacher. Students are often reluctant to speak because they are shy and are not predisposed to expressing themselves in front of other people, especially when they are asked to give personal information or opinion. Frequently, there is a worry about speaking badly and therefore losing face in front of their classmates (Harmer, 2012). Engaging students in brainstorming activities before the oral/speaking task to generate ideas is a good strategy for the language class. Brainstorming allows the students to create a context for the subsequent speaking task (Cullen, 1998).

In classes, where all or a number of the learners share the same mother tongue, they may tend to use it: because it's easier, and it feels unnatural to speak to one another in a foreign language, and because they feel less 'exposed' if they are speaking their mother tongue. If they are talking in small groups it can be quite difficult for the teachers to get some classes particularly the less disciplined or motivated ones - to keep to the target language. Lightbown 
\& Spada (2006) state that:

In a teacher's mind motivated students are those who participate actively in class, express interest in subject matter and study a great deal. Teachers also have more influence on those behaviours and the motivation they represent than on students' reasons for studying the second language or their attitude toward the language and its speakers. Teachers can make a positive contribution to students' motivation to learn if classroom are places that students enjoy coming to because the content is interesting and relevant to their age and level of ability, the learning goals are challenging yet manageable and clear, and the atmosphere is supportive

In the likewise context, Nunan (1991) wrote that: "Success (in the classroom) is measured in terms of the ability to carry out a conversation in the (target) language. Therefore, if students are not given opportunities to speak English in the language classroom they may soon get -demotivated and loose interest in learning". Learning is an active process within the pupil and when acquiring new knowledge motivation has a decisive influence on the result, as Ericsson (1993:74-75) would say it.

Social anxiety disorder is the most common anxiety disorder and is the third most common psychiatric disorder in the USA (Muzina \& ElSayegh, 2001). Unlike the usual nerves experienced by many people in new social situations, this condition makes the sufferers feel distressed, particularly when engaging in such activities as public speaking, asking questions, giving reports in groups, expressing disagreement and speaking in class, because they feel that they will embarrass themselves and that others are judging them negatively. As Muzina \& ElSayegh (2001:653) explain it: "They frequently judge themselves harshly and perceive others' reactions to their performance as negative". As a result, sufferers either avoid such stress inducing situations or undergo psychological distress and physical reactions such as tachycardia, increased blood pressure, trembling, shaking voice, shortness of breath, sweating and poor eye contact (Muzina and ElSayegh, 2001:652). Such types of problems can be overcome by providing students enough chances to practice their learned language in and outside the classroom.

\section{Literature Review}

Few studies have examined developing communicative competence in general and the students' speaking skills in particular. For example, Jassem (1997) was particularly interested in tackling and enhancing Malaysian English majors' skills in academic discussions by using various methods such as written assignment-oriented seminars. This is an interesting work as it handles an EFL/ESL context similar to the one at hand, where Malaysians are usually silent; they are keen on listening rather than speaking (as mentioned in Aljuma, 2011). Lee (2009) has examined the reasons for Asian students' low participation in class in Australia through combining both writing and speaking. Aljuma (2011) also noted that:

In ESL/EFL classroom interaction, teachers and students are often on opposing sides with one another: teachers babble all the time, whereas students mumble and swallow their words, or say nothing. Almost all such teachers and lecturers, therefore, complain 
about the unwillingness of their students to talk and communicate. This may be particularly frustrating to some of them, especially when they receive no feedback or response for their questions. This is a common phenomenon to all ESL or EFL contexts, especially the latter, no matter whether the teacher is local or foreign.

Numerous reasons why students may be reluctant to speak up in the classroom have been identified in literature. For instance, students may feel nervous at the thought of speaking out loud whilst in the presence of a large group (Turk, 1985; Cottrell, 1999; Bryan, 2001; McCarthy \& Hatcher, 2002). Petress (2001:3) refers to this as "Communication apprehension - a clinical fear of communicating with or in the presence of others". While the fear of speaking may prevent some students from speaking in seminars altogether, those who speak sometimes find their nerves restrict them from adequately sharing their views and intelligence, resulting in embarrassed and unconfident students who then promise themselves never to speak up again. Students may feel fear at the possibility of embarrassing themselves and appearing foolish or saying the 'wrong' thing.

\section{Research Methodology}

The current research involved exploring the Saudi students' perceptions about the importance of English communication, their existing level of communication skills and the need of participating in extra coaching sessions. A survey design was selected for this research in which a structured questionnaire was used to collect data. The questionnaire was administered with the help of head teachers and class representatives. The students completed questionnaire at the spot and the average time for filling up the questionnaire was recorded as 20 minutes.

\subsection{Participants}

The expected population for this research was 300 students from the Engineering, Computer Science and Business male students. However, due to time constraints, 124 students could be approached who belonged to the $1^{\text {st }}$ year of education.

\subsection{Research Tool (Questionnaire)}

A structured questionnaire was used to collect data for this research. It was based on the model of Norton (1980) which was used with 50 items and 10 factors to measure communication level of the students. The items in the model questionnaire were molded and resized keeping in view the objectives of this research. Hence, the number of items was 42 in the modified questionnaire. However, five items from the questionnaire were dropped which had loading less than 0.4 on the rotated component matrix. So, 37 items were finalized for reporting and data analysis. In the questionnaire, a Likert Scale with five options was used after Dornyei \& Taguchi (2010), i.e. Strongly Agree (SA), Agree (A), Neutral (N), Disagree (D), and Strongly Disagree (SD). For the positive items on the Likert scale, scoring was made such as 5 was given to the highest and 1 to the lowest, i.e. from strongly agree to strongly disagree. This scoring was reversed for the items which had negative connotations. For the purpose of making the questionnaire easy for the students, the items of questionnaire were translated into Arabic language, and the both versions of English and Arabic of the 
questionnaire were distributed among the students at the time of data collection. However, all the students preferred to fill in the questionnaire in Arabic language which, in fact, requires more elaborations as to why the hundred percent of students chose the Arabic version despite the fact that the teachers who were assigned the responsibility of collecting data explained every item to the students in English. The questionnaire was twice pilot tested with 20 students each time with a purpose of validation, and some modifications were made accordingly. The reliability of the questionnaire was measured as 0.71 at Cronbach Alpha which is not very high though, yet acceptable keeping in view the practices of research in social sciences.

\section{Analysis of Data}

The Orthogonal Varimax Technique which is considered to be useful in minimizing individual variables (Tabeachink \& Fidell, 2013) was used for data analysis in this study, also following a sum score factorization as advocated by Comrey \& Lee (1992) 'if an item yields a negative factor loading, the raw score of the item is subtracted in the computations because the item is negatively related to the factor'. Hence, the item statements which had a loading less than 0.4 were discarded, following Bradford (2007). Secondly, Mean and Standard Deviation were used to calculate variance of the individual items which is a norm of measuring dispersion of a set of data for its calculated Mean. The data is presented below with descriptive statistics of factors and Rotated Component Matrix with reference to the identified factors.

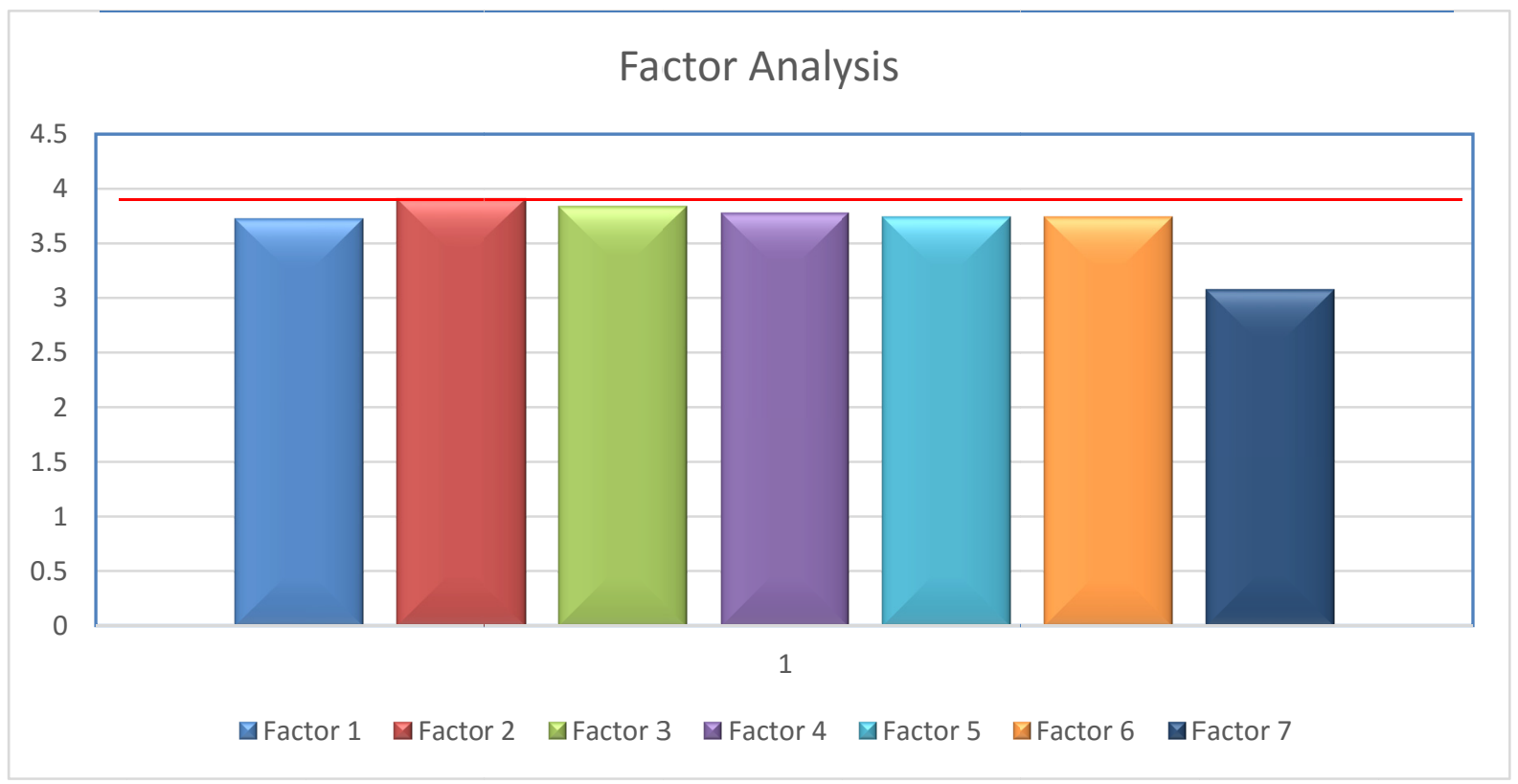

The seven colors in the graph above depict the result of the questionnaire on seven factors, i.e. students' perception about the importance of communicative competence, students' perception about their taking extra coaching for improving their conmunication skills, students' perception about their motivational level towards English communication, students' perception about their participation in classroom activities for improving communicative 
competence, students' perceptions about the social needs of communication skills, students' perceptions about communication and personality development and students' perceptions about their existing level of English Communication respectively. The graph depicts near to the real situation of the students' proficiency in English language. Despite learning English as a second/foreign language for eight years at various levels in education, they feel uncomfortable in expressing themselves in front of others either on national or international level. It also depicts their understanding about improving communicative competence and taking extra language training sessions to improve it. The following is a detailed account of the seven factors involved in this study.

Table 1. Factor 1, Students' perception about the importance of Communicative Competence

\begin{tabular}{|c|l|c|c|c|c|}
\hline $\begin{array}{c}\text { Item } \\
\text { No. }\end{array}$ & \multicolumn{1}{|c|}{ Statements } & N & Mean & SD & RCM* \\
\hline 1 & $\begin{array}{l}\text { I believe that good communication skills are } \\
\text { important for success in life. }\end{array}$ & 124 & 3.9758 & 0.8010 & 0.653 \\
\hline 2 & $\begin{array}{l}\text { I think English is very important for my } \\
\text { education. }\end{array}$ & 124 & 4.0161 & 0.8457 & 0.723 \\
\hline 3 & $\begin{array}{l}\text { I think my speaking ability helps me getting } \\
\text { good grades in class. }\end{array}$ & 124 & 3.6290 & 0.8011 & 0.598 \\
\hline 4 & $\begin{array}{l}\text { I feel English communication is important for a } \\
\text { job interview. }\end{array}$ & 124 & 3.7661 & 0.8844 & 0.593 \\
\hline 5 & $\begin{array}{l}\text { Good communications skills are important for } \\
\text { survival in a job. }\end{array}$ & 124 & 3.5081 & 0.8788 & 0.673 \\
\hline
\end{tabular}

* RCM= Rotated Component Matrix

The items identified in this factor were related to students' perceptions about the importance of English communication. All the items had loading more than 0.4 which shows their gravity on factorization. The highest loading on rotated component matrix was with item No. 2 (0.723) 'I think English is very important for my education', while the lowest was on item No. 4 (0.593) 'I feel English communication is important for a job interview'. The students' response on all the items was mid positive to highly positive with the highest mean score on item No. 2 (4.0161) and the lowest on item No. 5 (3.5081). The variance on individual items was on item No. $4(0.88445)$ as the highest and item No. 1 (0.80105). Over all, the items show clearly positive perceptions of the students regarding the importance of English communication.

Table 2. Factor 2, Students' perception about their taking extra coaching for improving their communication skills

\begin{tabular}{|c|l|c|c|c|c|}
\hline $\begin{array}{c}\text { Item } \\
\text { No. }\end{array}$ & \multicolumn{1}{|c|}{ Statements } & N & Mean & SD & RCM* \\
\hline 1 & $\begin{array}{l}\text { I think I need to take some extra classes to } \\
\text { improve my communication. }\end{array}$ & 124 & 3.9113 & 0.8460 & 0.995 \\
\hline
\end{tabular}




\begin{tabular}{|c|l|c|c|c|c|}
\hline 2 & $\begin{array}{l}\text { The university should arrange special classes to } \\
\text { improve my communication. }\end{array}$ & 124 & 3.8790 & 0.8224 & 0.420 \\
\hline 3 & $\begin{array}{l}\text { I think taking extra coaching is not a wastage of } \\
\text { my time. }\end{array}$ & 124 & 4.0161 & 0.8153 & 0.693 \\
\hline 4 & $\begin{array}{l}\text { I believe time spent of learning English is my } \\
\text { investment for future. }\end{array}$ & 124 & 3.8226 & 0.8746 & 0.559 \\
\hline 5 & $\begin{array}{l}\text { I think my parents will promote my efforts in } \\
\text { taking extra classes. }\end{array}$ & 124 & 3.9113 & 0.8460 & 0.715 \\
\hline
\end{tabular}

$* \mathrm{RCM}=$ Rotated Component Matrix

The items identified in factor No. 2 were related to students' perceptions, about taking extra coaching for improving their communication skills. All the items had loading more than 0.4 which shows their gravity on factorization. The highest loading on rotated component matrix was with item No. $1(0.995)$ 'I think I need to take some extra classes to improve my communication', while the lowest was on item No. 2 (0.420) 'The university should arrange special classes to improve my communication'. The students' response on all the items was highly positive with the highest mean score on item No. 3 (4.0161) and the lowest on item No. 4 (3.8226). The variance on individual items was on item No. $4(0.87465)$ as the highest and item No. 3 (0.81529). Over all, the items show clearly positive perceptions of the students regarding taking extra coaching in the university to improve their communicative competence.

Table 3. Factor 3, Students' perception about their motivational level towards English Communication

\begin{tabular}{|c|l|c|c|c|c|}
\hline Item No. & \multicolumn{1}{|c|}{ Statements } & N & Mean & SD & RCM* \\
\hline 1 & $\begin{array}{l}\text { I mostly feel motivated when the teacher } \\
\text { asks me anything in class. }\end{array}$ & 124 & 3.5565 & 0.9044 & 0.511 \\
\hline 2 & $\begin{array}{l}\text { I like an English teacher who let the } \\
\text { students speak most of the time. }\end{array}$ & 124 & 3.8790 & 0.8610 & 0.613 \\
\hline 3 & $\begin{array}{l}\text { I like a class where I have a lot of } \\
\text { opportunity to speak English. }\end{array}$ & 124 & 4.0161 & 0.8457 & 0.707 \\
\hline 4 & $\begin{array}{l}\text { I feel my environment supports me fully } \\
\text { for learning English. }\end{array}$ & 124 & 3.8226 & 0.8746 & 0.697 \\
\hline 5 & $\begin{array}{l}\text { I believe learning a new language is like } \\
\text { opening a new window in my mind. }\end{array}$ & 124 & 3.9113 & 0.8240 & 0.499 \\
\hline
\end{tabular}

*RCM= Rotated Component Matrix

The items identified in factor No. 3 were related to students' perceptions about their motivational level towards learning English communication. All the items had loading more than 0.4 which shows their gravity on factorization. The highest loading on rotated component matrix was with item No. 3 (0.707) 'I like a class where I have a lot of 
opportunity to speak English', while the lowest was on item No. 5 (0.499) 'I believe learning a new language is like opening a new window in my mind'. The students' response on all the items was highly positive with the highest mean score on item No. 3 (4.0161) and the lowest on item No. 1 (3.5565). The variance on individual items was on item No. $1(0.90439)$ as the highest and item No. 5 (0.82396). Over all, the items show clearly positive perceptions of the students regarding their perceptions on their motivational level and support for the enhancement of their communication skills.

Table 4. Factor 4, Students' perception about their participation in classroom activities for improving Communicative Competence

\begin{tabular}{|c|l|c|c|c|c|}
\hline Item No. & \multicolumn{1}{|c|}{ Statements } & N & Mean & SD & RCM* \\
\hline 1 & $\begin{array}{l}\text { I give a lot of arguments to prove my point } \\
\text { of view during communication with others. }\end{array}$ & 124 & 3.8226 & 0.8746 & 0.612 \\
\hline 2 & $\begin{array}{l}\text { I acknowledge others contribution in a } \\
\text { group event. }\end{array}$ & 124 & 3.7661 & 0.8844 & 0.618 \\
\hline 3 & $\begin{array}{l}\text { I react in such a way that others think I am } \\
\text { listening carefully. }\end{array}$ & 124 & 3.9758 & 0.8011 & 0.527 \\
\hline 4 & $\begin{array}{l}\text { I think the teacher should use only English } \\
\text { language in English class. }\end{array}$ & 124 & 3.5565 & 0.9044 & 0.633 \\
\hline
\end{tabular}

* RCM $=$ Rotated Component Matrix

The items identified in factor No. 4 were related to Students' perception about their participation in classroom activities for improving communication skills. All the items had loading more than 0.4 which shows their gravity on factorization. The highest loading on rotated component matrix was with item No. 4 (0.633) 'I think the teacher should use only English language in English class, while the lowest was on item No. 3 (0.527) 'I react in such a way that others think I am listening carefully'. The students' response on all the items was highly positive with the highest mean score on item No. 3 (3.9758) and the lowest on item No. 4 (3.5565). The variance on individual items was on item No. 9 (0.90439) as the highest and item No. 3 (0.80105). Over all, the items show clearly positive perceptions of the students regarding their perceptions on participation in classroom activities to improve their communication skills.

Table 5. Factor 5, Students' perceptions about the social needs of Communication skills

\begin{tabular}{|c|l|c|c|c|r|}
\hline Item No. & \multicolumn{1}{|c|}{ Statements } & N & Mean & SD & RCM* \\
\hline 1 & $\begin{array}{l}\text { I think that communication in English brings } \\
\text { social prestige. }\end{array}$ & 124 & 3.5081 & 0.8788 & 0.675 \\
\hline 2 & $\begin{array}{l}\text { I believe my country can develop fast with } \\
\text { promoting English communication. }\end{array}$ & 124 & 3.9274 & 0.8850 & 0.437 \\
\hline 3 & $\begin{array}{l}\text { I think English communication is not a } \\
\text { barrier for my social participation. }\end{array}$ & 124 & 3.7500 & 0.8892 & 0.968 \\
\hline
\end{tabular}




\begin{tabular}{|c|l|c|c|c|c|}
\hline 4 & $\begin{array}{l}\text { I am sure that people wouldn't wonder if I } \\
\text { say something in English. }\end{array}$ & 124 & 3.6532 & 0.9461 & 0.667 \\
\hline 5 & My society promote learning new languages. & 124 & 3.8790 & 0.8610 & 0.656 \\
\hline
\end{tabular}

\section{*RCM= Rotated Component Matrix}

The items identified in factor No. 5 were related to Students' perception about the social needs of communication skills. All the items had loading more than 0.4 which shows their gravity on factorization. The highest loading on rotated component matrix was with item No. 3 (0.968) 'I think English communication is not a barrier for my social participation'. While the lowest was on item No. 2 (0.437) 'I believe my country can develop fast with promoting English communication.' The students' response on all the items was highly positive with the highest mean score on item No. 2 (3.9274) and the lowest on item No. 1 (3.5081). The variance on individual items was on item No. $4(0.94606)$ as the highest and item No. 2 (0.88505). Over all, the items show clearly positive perceptions of the students regarding the social needs of improving their communication skills.

Table 6. Factor 6, Students' perceptions about communication and personality development

\begin{tabular}{|c|l|c|c|c|c|}
\hline Item No. & \multicolumn{1}{|c|}{ Statements } & N & Mean & SD & RCM* \\
\hline 1 & $\begin{array}{l}\text { I feel my communication skills have very } \\
\text { good impact on my personality. }\end{array}$ & 124 & 3.5081 & 0.8788 & 0.620 \\
\hline 2 & $\begin{array}{l}\text { I feel good that my communication skills } \\
\text { attract others. }\end{array}$ & 124 & 3.9274 & 0.8850 & 0.580 \\
\hline 3 & $\begin{array}{l}\text { I believe I will be a confident person if I speak } \\
\text { good English. }\end{array}$ & 124 & 3.7500 & 0.8892 & 0.759 \\
\hline 4 & $\begin{array}{l}\text { I think English will make me adjustable in the } \\
\text { international community. }\end{array}$ & 124 & 3.6532 & 0.9461 & 0.488 \\
\hline 5 & $\begin{array}{l}\text { I feel myself high in a society where very few } \\
\text { people use two or more languages. }\end{array}$ & 124 & 3.8790 & 0.8610 & 0.564 \\
\hline
\end{tabular}

$* \mathrm{RCM}=$ Rotated Component Matrix

The items identified in factor No. 6 were related to Students' perception about their communication skills and their personality development. All the items had loading more than 0.4 which shows their gravity on factorization. The highest loading on rotated component matrix was with item No. 3 (0.759) 'I believe I will be a confident person if I speak good English', while the lowest was on item No. 4 (0.488) 'I think English will make me adjustable in the international community'. The students' response on all the items was highly positive with the highest mean score on item No. 2 (3.9274) and the lowest on item No. 1 (3.5081). The variance on individual items was on item No. 4 (0.94606) as the highest and item No. 5 (0.86101). Over all, the items show clearly positive perceptions of the students regarding the importance of English communication for their personality development. 
Table 7. Factor 7, Students' perceptions about their existing level of English Communication

\begin{tabular}{|c|c|c|c|c|c|}
\hline $\begin{array}{l}\text { Item } \\
\text { No. }\end{array}$ & Statements & $\mathbf{N}$ & Mean & SD & RCM* \\
\hline 1 & I am very fluent in expressing my ideas. & 124 & 3.0484 & 1.019 & 0.706 \\
\hline 2 & I think my pronunciation is very good. & 124 & 2.5484 & 0.877 & 0.704 \\
\hline 3 & $\begin{array}{l}\text { I feel that my speaking style is acceptable for } \\
\text { others. }\end{array}$ & 124 & 2.9919 & 1.024 & 0.749 \\
\hline 4 & $\begin{array}{l}\text { I usually have enough vocabulary to express } \\
\text { myself. }\end{array}$ & 124 & 2.9677 & 0.953 & 0.622 \\
\hline 5 & $\begin{array}{l}\text { I am not afraid of taking IELTS or TOEFL for } \\
\text { going abroad. }\end{array}$ & 124 & 3.2661 & 1.183 & 0.636 \\
\hline 6 & I feel myself a good communicator. & 124 & 3.5000 & 0.770 & 0.692 \\
\hline 7 & $\begin{array}{l}\text { While speaking, I use non-verbal cues (body } \\
\text { language) also. }\end{array}$ & 124 & 3.2258 & 1.139 & 0.703 \\
\hline
\end{tabular}

\section{* RCM= Rotated Component Matrix}

The items identified in factor No. 7 were related to Students' perception about their existing level of communication skills. All the items had loading more than 0.4 which shows their gravity on factorization. The highest loading on rotated component matrix was with item No. 3 (0.749) 'I feel that my speaking style is acceptable for others', while the lowest was on item No. 4 (0.622) 'I usually have enough vocabulary to express myself'. The students' response on all the items was mid positive with the highest mean score on item No. 6 (3.5000) and the lowest on item No. 2 (2.5484). The variance on individual items was on item No. 4 (1.139) as the highest and item No. 6 (0.770). Over all, the items show students' low confidence on their existing level of English communication.

\section{Conclusion}

The data may help us concluding that the students of Jazan University, Saudi Arabia are fully aware of the importance of learning English in general and improving their oral communication skills in particular - for social prestige, getting jobs and sustaining in a highly competitive market economy like Saudi Arabia. They have clear ideas about their motivational level towards learning English language for communicative purpose. It also expressed their willingness to participate in extra coaching sessions for improving their communicative competence. The data also shows that the participants got the lowest score on the factor of their current level of speaking ability which clearly means their understanding on the issue and their willingness to improve the situation. EFL learners' reluctance to speak 
English in the classroom is a problem commonly found in EFL contexts (Ahmad \& Rao, 2013).

\subsection{Discussion}

An important aspect of learning English for students is to be able to communicate what they know. The best way for the teachers is to encourage communication from all students through discussion or small groups work. Keeping in view the importance of practising oral communication of the students, Deepa (2012) asserted that:

Oral communication fulfils a number of general discipline specific academic functions. Students need to speak well in their personal life, future workplace, social interactions, and political endeavours. They will have to attend meetings, make presentations, participate in discussions and arguments, and work with groups. If necessary instruction and opportunities to practice speaking are available, students place themselves to achieve a wide range of goals and become useful members of their communities.

The research shows that the EFL/ESL learners develop negative attitudes to speaking and are likely to lack motivation to put more efforts in it. The ability to communicate in a foreign/second language clearly and efficiently contributes a great deal to the success of the learners during their educational career and later at any phase of their life. Scrivener (2012) says that "without experience in using the language, learners may tend to be nervous about trying to say things. Partly they may fear seeming foolish in front of others; they may worry about getting things wrong; they may want to avoid the comments or corrections; and so on". Making students practice communicative activities such as discussions, role-plays, story-telling and interviews to maximise learning, to bring excitement in the classroom and to promote speaking as a whole are some of the most common communicative language teaching practices. Nunan (1989) suggests that the communicative tasks will contain a goal, input, activities, settings and roles. Goals of tasks are to develop students' communicative competence including socio-linguistic competence, discourse competence and strategic competence. Tasks may contain some form of input data which might be verbal (for example a dialogue or reading passage) or non-verbal (for example a picture sequence). Activity refers to tasks, not exercises. An activity is in some ways derived from the input and sets out what the learners are to do in relation to the input. A crucial part of the teacher's job when organising speaking activities is to make sure that the students understand exactly what they are supposed to do. This involves giving clear instructions and, where appropriate, demonstrating the activity with a student or students so that no one is in any doubt about what they should be doing (Harmer, 2012).

\section{References}

Ahmad, S., \& Ahmad, N. (2015). Fostering Inter-Cultural Communication Skills among Learners through Teaching English as an International Language. International Journal of Applied Linguistics and English Literature, 4(6).

Ahmad, S., \& Rao, C. (2013). Applying Communicative Approach in Teaching English as a Foreign Language: A case study of Pakistan. Porta Linguarum, 20. 
Ahmad, S., \& Rao, C. (2012). Examination Washback Effect: Syllabus, Teaching Methodology and the Learners' Communicative Competence. Journal of Education and Practice, 3(15), 173-183.

AL-Ghunaimi, E. (2003). The Effectiveness of a Suggested Video Program on Developing the Communicative Skills of the 11th Grade Learners of English in Gaza Governorates, Unpublished Thesis. Faculty of Education. AL-Azhar University, Gaza.

Aljumah, H. (2011). Developing Saudi EFL Students' Oral Skills: An Integrative Approach, English Language Teaching, 4(3).

Bradford, A. (2007). Motivational Orientations in Under-researched FLL Contexts: Findings from Indonesia. RELC Journal, 38(3), 302-323.

Bryan, C. (2001). Presenting your case. In Stott R, Young T, and Bryan C. (Eds.). Speaking your Mind: Oral Presentation and Seminar Skills, Book 3 in the Speak-Write Series, Longmans. pp.106-122.

Byrne, W. (1999). Initiatives in Communicative Language Teaching. USA: Library of Congress.

Chanrung, K. (2004). A naturalistic Study of the Integration of Computer-mediated Communication Oral Discussion in an EFL college Classroom in Thailand. Retrieved November 23, 2005 from http://www.askerik.org. ED205531.

Comrey, A. L., \& Lee, H. B. (1992). A first course in factor analysis. Hillsdale, NJ: Erlbaum.

Cordova, D. I., \& Lepper, M. R. (1996). Intrinsic motivation and the process of learning: Beneficial effects of contextualization, personalization, and choice. Journal of Educational Psychology, 88(4).

Cottrell, S. (1999). The Study Skills Handbook. Basingstoke: Palgrave Macmillan.

Cullen, B. (1998). Brainstorming before Speaking Task. The Internet TESL Journal, 6 (7), retrieved on 24.08.2015 at http://iteslj.org/

Deepa. (2012). Task-Based Oral Communication Teaching. ESP World, 35, Vol. 12, http://www.esp-world.info

Dornyei, Z., \& Taguchi, T. (2010). Questionnaires in Second Language Research: Construction, Administration, and Processing (2nd ed.). London: Routledge.

EL-Majdalawi, R. (2005). The Main Factors Affecting English Classroom Interaction of the11th Grade Students in North Gaza Governmental Schools. Unpublished MA Thesis. The Islamic University of Gaza.

Ericson, K. A. (1993). The Role of Deliberate Practice in the Acquisition of Expert Performance. Psychological Review, 100(3), 363-406.

Gillian, B. (2005). The Importance of Oral Language in the School Curriculum. Unpublished M.A Dissertation, New York University. 
Harmer, J. (2012). The Practice of English Language Teaching. Longman.

Jassem, Z. A. (1997). Towards better speaking in the English class: A Sociolinguistic Approach. The English Teacher, 24, 41-52.

Johnson, K., \& Marrow, K. (1986). Communication in the Classroom, London: Longman.

Lee, G. (2009). Speaking up: Six Korean Students' Oral Participation in Class Discussions in US Graduate Seminars. English for Specific Purposes, 28, 142-156.

Lightbown, P., \& Spada, N. (2006). How Languages are Learned, Oxford University Press.

McCarthy, P., \& Hatcher, C. (2002). Presentation Skills, the Essential Guide for Students. London: Sage Publications Ltd.

Muzina, D. J., \& ElSayegh, S. (2001). Recognising and Treating Social Anxiety Disorder. Cleveland Clinical Journal of Medicine, 68, 7.

Norton, R. W. (1980). Dramatic Behaviours of the Effective Teacher. In D. Nimmo (Ed.). Communication year book 4 (pp.565-582). New Bernswick, NJ: Transaction.

Nunan, D. (1989). Designing Tasks for the Communicative Classroom. New York: Cambridge University Press.

Petress, K. (2001). The ethics of student classroom silence. Journal of Instructional Psychology, 28, 104-107.

Rababah, G. (2003). Communication Problems Facing Arab Learners of English: A Personal Perspective, TEFL Web Journal, 2, 1.

Scott, T. (2005). How to Teach Speaking English EFL Communication. ERIC No. EJ518418, accessible at http://www.askeric.org/

Scrivener, J. (2012). Learning Teaching, MacMillan Books for Teachers. Speaking Your Mind, Oral Presentation and Seminar Skills. England: Pearson Education Ltd, 106 -122, 491525.

Tabachnick, B. G., \& Fidell, L. S. (2013). Using Multivariate Statistics (6th ed.). London: Pearson.

Turk, C. (1985). Effective Speaking, Communicating in Speech. London: Chapman.

Ur, P. (2008). A Course in Language Teaching: Practice and Theory: Trainer's Handbook. Cambridge Teacher Training \& Development.

Yasmin, Y. (2004). An Investigation of English Language Learning Strategies Used by the Eleventh Grade Students in Learning English as A foreign Language in Governmental and Private Schools. Unpublished M.A Study, Education College, An-Najah National University, Nablus, Palestine. 


\section{Macrothink}

International Journal of English Language Education

ISSN 2325-0887

\section{Copyright Disclaimer}

Copyright for this article is retained by the author(s), with first publication rights granted to the journal.

This is an open-access article distributed under the terms and conditions of the Creative Commons Attribution license (http://creativecommons.org/licenses/by/3.0/). 